\title{
MULTI-TEMPORAL LAND USE/LAND COVER CHANGE DETECTION IN SEMI URBAN VELLORE DISTRICT USING LANDSAT TM AND ETM+ DATA
}

\author{
Nethaji Mariappan V. $\mathrm{E}^{1}$, Nagamani $\mathrm{K}^{2}$, Manoharan $\mathrm{N}^{3}$ \\ ${ }^{1}$ Scientist-D, ${ }^{2}$ Scientist-C, ${ }^{3}$ Vice Chancellor \\ Sathyabama University \\ Rajiv Gandhi Road, Jeppiaar Nagar, \\ Chennai - 600 119, Tamil Nadu, India
}

\begin{abstract}
Change detection is the measure of the distinct data framework and thematic change information that can guide to more tangible insights into underlying process involving land cover and land use changes than the information obtained from continuous change. Land use / Land cover analysis of the semi-urban area was carried out using Landsat TM and ETM+ imageries through Remote sensing software for Vellore district in Tamil Nadu, India. This study attempts to explore the changes along the study areas, two sets of Landsat Thematic Mapper (TM) data were used. TM data are useful for this type of study due to its high spatial resolution, spectral resolution and low repetitive acquisition (16 days).This paper discusses the land use/land cover analysis and change detection techniques using temporal multi-spectral data (1991 and 2001) of the LANDSAT TM images, systematically assessed, and checked in field. Initially 18 major classes were observed for both the images. To minimize similar features, relevant classes were reorganized to end up with 8 classes. The overall accuracy for a 1991 image is $78 \%$ and for a 2001 image is $80 \%$. The results demonstrate that the study area experienced a rapid, decrease in forest cover, conversion of wetland vegetation to barren / dry farming, rural to urban conversion in town and municipalities resulting in decreasing ground water table in the 10 year period between 1991 and 2001.
\end{abstract}

Key words: Land use/ Land cover, Remote sensing and Supervised Classification.

\section{INTRODUCTION}

Mankind's presence on the earth and his modification of a landscape has a profound effect on available land resources all over the region. This anthropogenic influence on shifting patterns of land use are a primary component of many environmental concerns as land use and land cover change is gaining recognition as a key driver of change in biogeochemical cycle.

Applications of remote sensing in agriculture include several aspects such as plant phenology, economic features, and land use management. These applications have been playing an important roll and suggest that remote sensing technology is and will be a powerful tool for monitoring agricultural activities (Allan, 1990).

The conventional ground methods of land use mapping are time consuming, labour intensive and are relatively infrequent. The maps thus prepared become out of date with the passage of time, particularly in a dynamic or rapidly changing environment. With the advent of remote sensing technology, particularly satellite remote sensing, techniques have been developed which proved to be of immense value in preparing land use / land cover maps and monitoring changes at periodic intervals. Thus, classification of a study area into different land use/cover types is one of the primary objectives of studies that use remote sensing technology (Moreno, 1991).

Many change detection techniques have been developed to detect land use / land cover changes using digital remote sensing data (Coppin and Bauer, 1996). The techniques can usually be separated into two main categories; post classification spectral change detection and pre classification change detection (Singh, 1989). Post classification methods involve the thematic classification of two different data images independently. Thematic maps are then further compared and analyzed to map the type of change (Lunetta 1998; Yuan et al. 2005).

The present study intends to monitor the changes in land use, which is important in the present scenario, as the ground water table of the study district is decreasing temporally and spatially. This may lead to harmful effect like drought and soil degradation. In order to overcome further land degradation, a study was 
undertaken to assess different land use categories and ascertain the current status of present land use system.

\section{A. Study area}

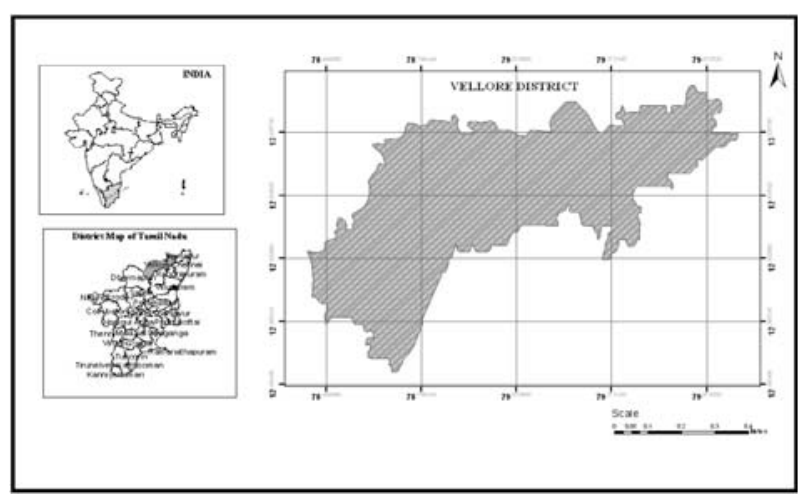

Fig. 1. Location map

The study area is Vellore district (6077 sq. km.) of Tamil Nadu. It lies between $78^{\circ} 20^{\prime}$ to $79^{\circ} 50^{\prime}$ East Longitudes and $12^{\circ} 15^{\prime}$ to $13^{\circ} 15^{\prime}$ North Latitude (Fig. 1). Major portion of the study area is covered by sandstone, which is of Pliocene formation. Other parts of the region are formed by Charnockite and a smaller part Pink Granite which is of Pre-Cambrian Age. The Climate is sub tropical and seasonal variations in temperature are very wide. Rainfall in this area is received through both southwest and north east monsoon. Maximum rainfall is received through North East Monsoon. The physiography of the region is dominated by (i) Eastern Ghats covering north and north western part; rainfed agriculture including sorghum, groundnut and pulses are cultivated (ii) Tamil Nadu plain (Lateritic land form) covering the southern and south eastern part; rainfed crops such as rice, groundnut, sorghum, pulses and major and minor millets are sown depending on ground water availability (iii) Tamil Nadu Upland covering southern and south western part of Vellore district; ground nut and rice are cultivated. The natural forest vegetation is predominantly dry deciduous forest, mixed forest and thorny shrubs. The forests are interspersed with areas of induced grass and mountain vegetation.

\section{B. Data Used}

Topographic sheets of Survey of India No 570 4, 8, 12, 16, 57P1,5,6,9 57K15,16 57L 9,10,11,13,14 $57 \mathrm{P} 1,5,6,9$ (Table-1) on 1:50000 scale. Data of Landsat TM, path-row 143 / 051, geocoded product dated April 1991 on 1:50,000 scale and Landsat ETM, path-row 143 / 051, geocoded standard data dated February 2001 on 1:50,000 scale were downloaded from the website $\mathrm{http}: / / \mathrm{glfc}$.umiacs.umd.edu/index.shtml. in table 2.

Table 1. Survey of India Topo sheets used

\begin{tabular}{|c|c|c|c|}
\hline Toposheet & $\begin{array}{c}\text { Year of } \\
\text { Publication }\end{array}$ & Scale & Source \\
\hline $\begin{array}{c}57 \mathrm{O} \\
4,8,12,16\end{array}$ & 1973 & $1: 50,000$ & Survey of India \\
\hline $\begin{array}{c}57 \mathrm{P} \\
1,5,6,6,9\end{array}$ & 1973 & $1: 50,000$ & Survey of India \\
\hline $57 \mathrm{~K} 15,16$ & 1973 & $1: 50,000$ & Survey of India \\
\hline $\begin{array}{c}57 \mathrm{~L} \\
9,10,11,13,14 \\
57 \mathrm{P} \\
1,5,6,9\end{array}$ & 1973 & $1: 50,000$ & Survey of India \\
\hline & 1973 & $1: 50,000$ & Survey of India \\
\hline
\end{tabular}

Table 2. Acquired satellite data and its sensors characteristics

\begin{tabular}{|c|c|c|c|c|c|}
\hline $\begin{array}{l}\text { S. } \\
\text { No. }\end{array}$ & Sensor & Characteristics & Path/Row & $\begin{array}{c}\text { Date of } \\
\text { acquisition }\end{array}$ & Data source \\
\hline 1 & $\begin{array}{c}\text { Landsat } \\
\text { MSS }\end{array}$ & $\begin{array}{l}\text { Spatial resolution }-57 \mathrm{~m} \\
\text { Spectral resolution }-8 \text { bit } \\
\text { Number of bands }-4\end{array}$ & $\begin{array}{l}\text { Path- } 172 \\
\text { Row - } 43 \\
\text { (WRS-1) }\end{array}$ & April, 1991 & $\begin{array}{c}\text { Global Land Cover Facility University of } \\
\text { Maryland USA. } \\
\text { http://glfc.umiacs.umd.edu/index.shtml. }\end{array}$ \\
\hline 2 & $\begin{array}{c}\text { Landsat } \\
\text { ETM }\end{array}$ & $\begin{array}{l}\text { Spatial resolution }-28 \mathrm{~m} \\
\text { Spectral resolution }-8 \text { bit } \\
\text { Number of bands }-7\end{array}$ & $\begin{array}{l}\text { Path-160 } \\
\text { Row- } 43 \\
\text { (Wrs-2) }\end{array}$ & Feb. 2001 & $\begin{array}{c}\text { Global Land Cover Facility University of } \\
\text { Maryland, USA } \\
\text { http://glfc.umiacs.umd.edu/index.shtml. }\end{array}$ \\
\hline
\end{tabular}

Source: http://glfc.umiacs.umd.edu/index.shtml. in 


\section{METHODOLOGY}

Base map was prepared from SOI topo sheets on 1:50,000 scale, selecting permanent features like major roads, railways, water bodies and settlement. Subsets of the study area were extracted from images obtained on April 1991 and February 2001. Landsat TM / ETM images were rectified and projected to Universal Transverse Mercator (UTM). Interpretations of land use I land cover were done with image contrast technique using ERDAS IMAGINE software. The ground truth information about land use/ land cover classes, crop types, and associated information was collected and the feature class such as forest classes and wetland / dry land crops cover were ascertained. Land use/ land cover classification was carried out for the year 1991 and 2001 by changing the national land use/land cover classes to regional classes in the study area. Digital image processing included the use of both in situ classification processes, whereby training sites that were representative of the land cover classes of interest were acquired through in situ information and on screen seeding. The detailed methodology is described in figure 1. The optimum spectral bands for land use / land cover classification; determined through graphic methods of feature selection such as bar graph spectral plots like wise green, red and near infra red bands of

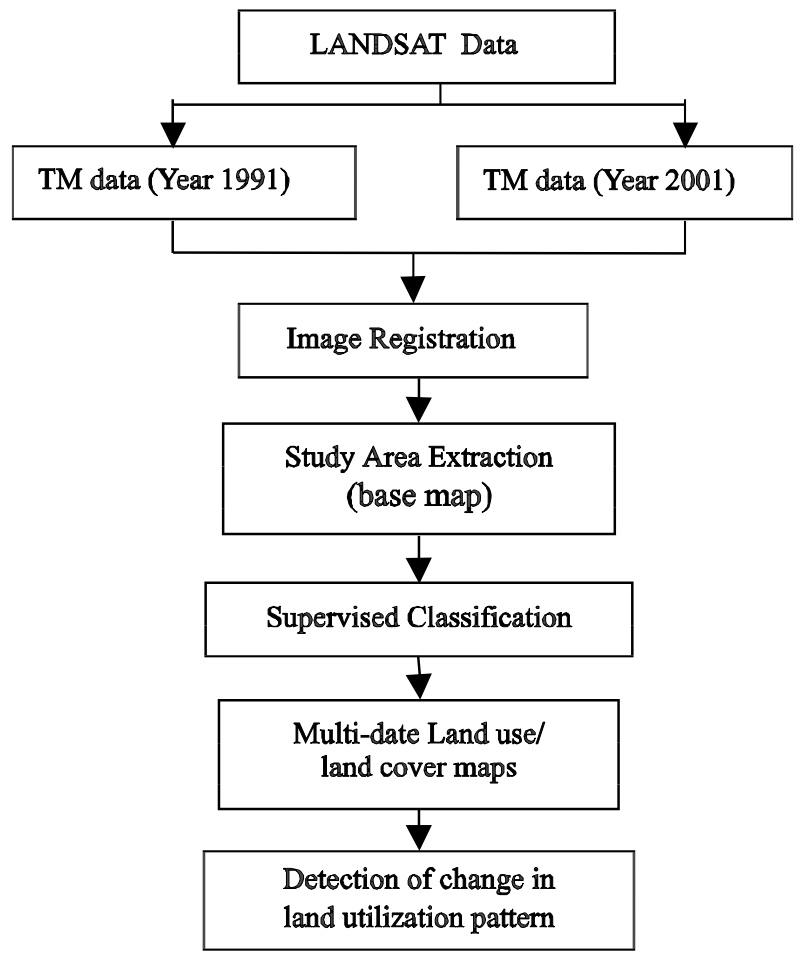

Flow chart 1: Methodology Adopted each image. Each land use/land cover class were digitized onscreen using ERDAS IMAGINE software and the area calculation for each representative classes were calculated in the same software. The area of land use / land cover class for the years 1991 and 2001 were given as input in MS excel software, the changes in each land cover category were computed.

\section{RESULTS AND DISCUSSION}

\section{A Land Use Classes}

According to primary classification of collected image following information were found of study area. Digital classification of the images determining the land use types. For the sake of simplicity eight types of land uses: Built-up /Urban, Agricultural land/Wetland vegetation, Sparse Vegetation and Upland Vegetation, Hill Vegetation, Hills without vegetation and Rock out crops, Barren Rock, Barren land, water bodies and Dry farming were selected for the study (Table 3).

Table 3. Land use/Land cover classes

\begin{tabular}{|l|l|}
\hline \multicolumn{1}{|c|}{$\begin{array}{l}\text { Land Use/Land } \\
\text { Cover Classes }\end{array}$} & \multicolumn{1}{|c|}{ Descriptions } \\
\hline Built up land/Urban & $\begin{array}{l}\text { Commercial services, industrial, } \\
\text { Institutional area, administrative area, } \\
\text { transportation, communications, Industrial } \\
\text { and communication, mixed urban or built } \\
\text { up land, other urban or built up land }\end{array}$ \\
\hline Agricultural land & $\begin{array}{l}\text { Cropland/pastureland, Tree Crops (other } \\
\text { than plantation monoculture), Feed Lots, } \\
\text { Nurseries, Specialty Farms, and Rural } \\
\text { Open Lands are sub-categories defined } \\
\text { under Agriculture. }\end{array}$ \\
\hline $\begin{array}{l}\text { Sparse Vegetation } \\
\text { and Upland } \\
\text { Vegetation }\end{array}$ & $\begin{array}{l}\text { Open-grown trees, scattered shrubs or } \\
\text { shrub thickets, and a partial turf of } \\
\text { herbs and grasses. }\end{array}$ \\
\hline Hill Vegetation & $\begin{array}{l}\text { Area under forest cover including most } \\
\text { of the tree species }\end{array}$ \\
\hline $\begin{array}{l}\text { Hills without } \\
\text { vegetation and } \\
\text { Rock out crops }\end{array}$ & Area covered by sparse vegetation \\
\hline Barren Rock & $\begin{array}{l}\text { Exposed rock and small scattered blank } \\
\text { patches }\end{array}$ \\
\hline Barren land & $\begin{array}{l}\text { Extractive land/ land not being cultivated } \\
\text { for a short span }\end{array}$ \\
\hline Dry farming & Tanks and Rivers \\
\hline Farming without a source for irrigation
\end{tabular}




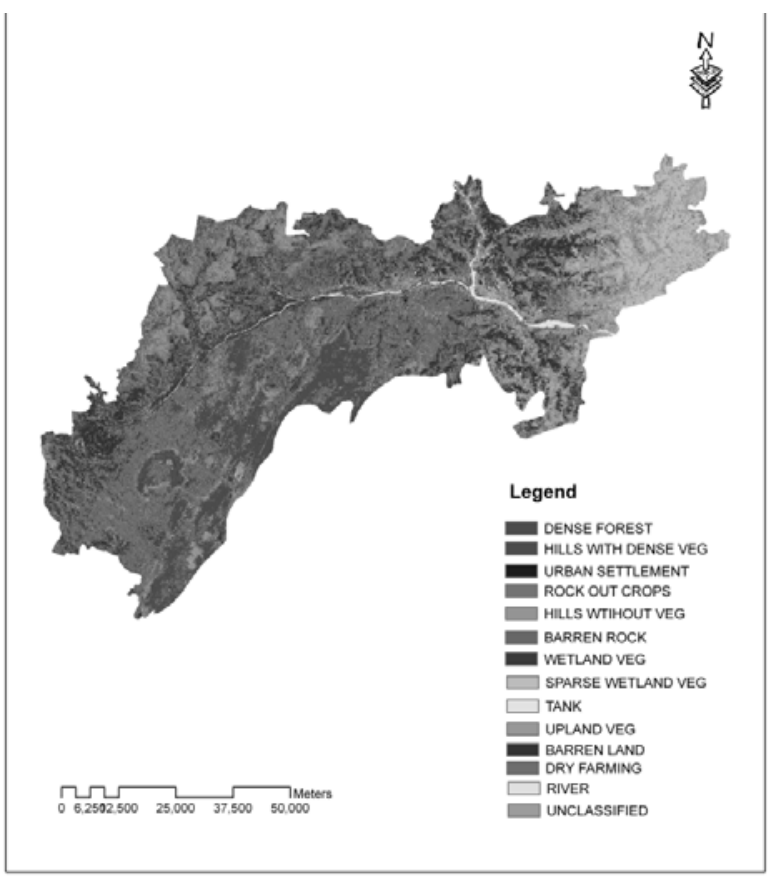

Fig. 2. Land Use /Land Cover Classes of the year

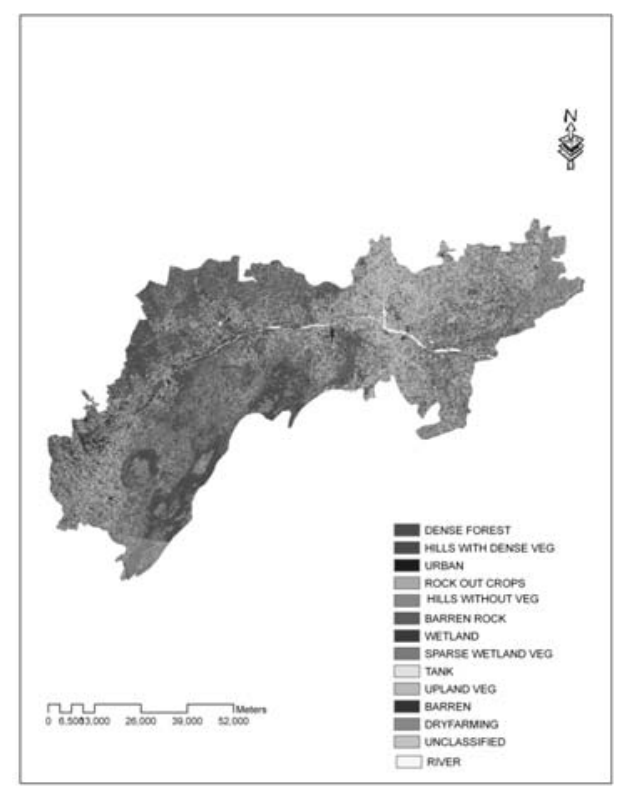

Fig. 3. Land use / Land cover classes of the year 2001 derived from Landsat ETM+ data

The figures 2 and 3 show the land use /land cover map pertaining to Vellore district for the year 1991 and 2001 respectively.

\section{B. Built up Land/ Urban settlement}

It is defined as an area occupied by human habitation developed due to non-agricultural use and which has cover of buildings, transport, communications, and utilization in association with water, vegetation and vacant lands. Built up area was observed in the all types of terrain, like agricultural lands, forests and wastelands in association with rail, road and canal networks. They appear distinctly between the crop lands of Kharif and Rabi seasons. As there are no urban areas, the rural settlements present in the study area can be identified in the satellite imageries through enhancement techniques, they are very small in extent comprising a total area of about $1830.1 \mathrm{Ha}$ in 1991 and $10974.0 \mathrm{Ha}$ in 2001 accounting 0.3 per cent in 1991 and 1.8 per cent in 2001 respectively.

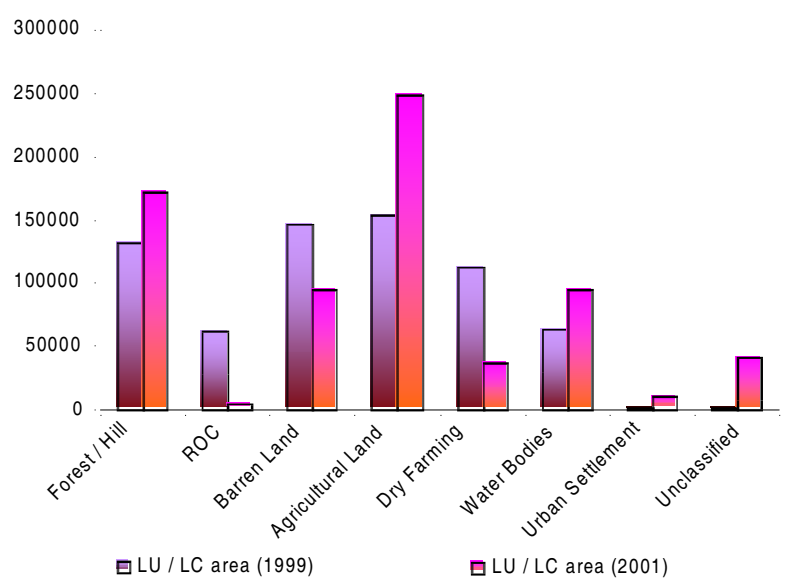

Fig. 4. Land use / land cover area statistics for the period 1991 and 2001 derived from Landsat data Note : Values of $Y$ axis are given in hectares

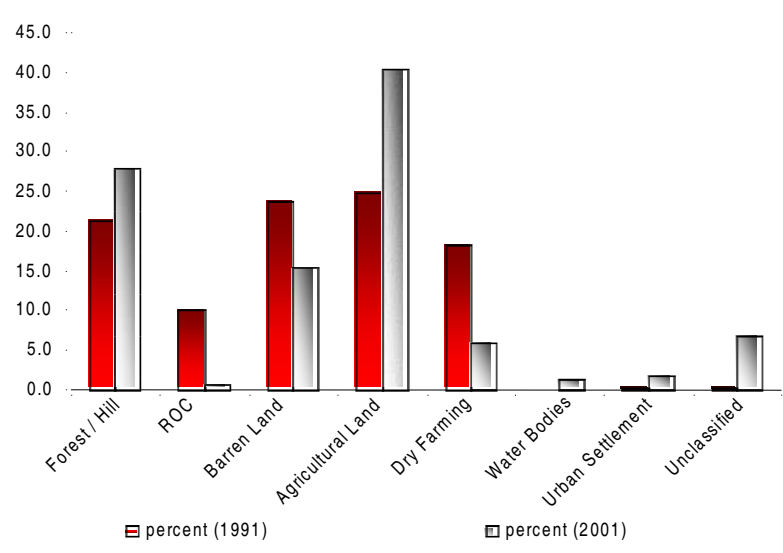

Fig. 5. Land use / land cover per cent area for the period 1991 and 2001 derived from Landsat data 


\section{Agricultural Land/ wetland vegetation}

It is defined as the land primarily used for farming and for production of food, fibre and other commercial and horticultural crops. It includes land under crops, plantations etc., in the basin is the irrigated area which occupies 27939.0 ha in 1991 accounting for 4.5 per cent of the total area. The total wetland vegetation area of 62435.1 ha with a 10.1 per cent was observed in the year 2001 depicted in figure 4 \& 5 .

\section{Sparse vegetation and upland vegetation}

Area usually covered by thin vegetation due to low ground water potential. A single crop is generally seen that too depending upon water availability of that locality. The combined area of upland and sparse vegetation was of 125213.4 ha and 20.3 per cent during the year 1991. In the span of 10 years at 2001 the area has risen to 186488.2 ha and of 30.2 per cent of the total.

\section{E. Hill Vegetation (Dense hill, Hill with dense vegetation)}

It is an area bearing an association predominantly of trees and other vegetation types capable of producing timber and other forest products. These occur on the higher reaches of hill slopes coinciding with zones of very high rainfall. Degraded forest was also observed in this study, described as a forest, where the vegetative density is less than 10-40 per cent of the canopy cover. Degraded forest occur on mountain / hill slopes, isolated hills, uplands in association with different forest types and sub types within the notified forest area. The hills with dense vegetation account for about 72251.1 ha and 102430.7ha, accounting 11.7 and 16.6 percent for the years 1991 and 2001 respectively in figure 4 \& 5 .

\section{F. Hills without Vegetation and Rock out crops}

Rock out crops refers to undulating hilly terrain with sparse vegetation in the form of trees and shrubs that are occasionally observed in the locality. Hills without vegetation are also similar to rock out crops except that barren rock may not be available in the region. The total area including Hills without vegetation and Rock out crops was of 115161.2 ha with 18.6 per cent for the year 1991. The area reduced to 73324.4 ha to the extent of 10.0 per cent of the total geographical area.

\section{G. Barren Rock}

It is defined as rocky exposure of varying lithology often barren and devoid of soil cover and vegetation. They occur amid hill forests as opening or scattered as isolated exposures or loose fragments, boulders or as sheet rocks or plateaus and plains. It occurs in steep hill slopes, crest, isolated hillocks, plateau and eroded plains in association with barren and exposed rocks. Barren rock outcrops cover an area of about 52521.7 ha and 58287.6 ha accounting for 8.5 per cent to 9.4 per cent for the periods 1991 and 2001 respectively.

\section{H. Barren land}

It is more like a grazing land where occasional shrubs with grasses and land with undulating topography is seen. Barren lands are usually observed along the foothills. It accounts for 94140.3 ha covering an aerial extent 15.2 per cent in 1993 . The extent has rose to 36862.6 ha with 6.0 per cent for the year 2001 .

\section{Water bodies: (tank and river)}

This is an area of impounded water of natural or man made enclosed water body with regulated flow of water. Tanks are smaller in aerial extent with limited use than the former. Canals are inland waterways used for irrigation and sometimes for navigation. Tanks and canals were dry during the period of investigation.

\section{J. Dry farming}

Farming system adopted in areas having an annual rainfall of approximately 15 to 20 in. with much of the rainfall in early summer, where irrigation is impractical. Seeding rates are ascertained according to the soil water supply; management practices. The land is often summer-fallowed in alternate years to conserve moisture. Dry-land crops must be either drought-resistant, special varieties of crops such as sorghum, finger millet and pearl millet are often used as dry land crops. The area under dry land farming was of 112945.5 ha covering 18.3 per cent of the geographic area has been reduced to 37141.3 ha of 6.0 per cent for the year 2001. The decrease in area was due to the conversion of dry farming to barren land in the past years.

\section{CONCLUSION}

The change detection analysis is an efficient way of describing the changes observed in each land use category. Over a decade there were considerable 
variations in agricultural land, hilly area with vegetation and in dry farming. Supervised classification of Landsat images and cross verification by ground truth traverse has resulted an overall accuracy of the image interpretation classes. A high resolution satellite data would suitably improve the land use classification.

\section{REFERENCES}

[1] Moreno, J.F., 1991. Discriminacio n y clasificacio n. In: Gandia, S., Melia, J. (Eds.), La teledeteccio $n$ en el seguimiento de los feno menos naturales. Recursos renovables: Agricultura. Curso de Postgrado, Universitatde Valencia, Unidad Investigacio $n$ en Teledeteccio n, Espan a, pp. 241-271.

[2] Allan, J.A., 1990. Sensors, platforms and applications; acquiring and managing remotely sensed data. In: Steven, M.D, Clark, J.A. (Eds.), Applications of Remote Sensing in Agriculture. Butterworths, The University of Nottingham, Great Britain University Press Cambridge, pp. 3-18.

[3] Coppin, P. L., \& Bauer, M. E. (1996). Change detection in forest ecosystems with remote sensing digital imagery. Remote Sensing Reviews, 13, 207-234.

[4] Singh, A. (1989). Digital change detection techniques using remotely-sensed data. International Journal of Remote Sensing, 10, 989-1003.
[5] Yuan, F., Sawaya, K. E., Loeffelholz, B. C., \& Bauer, M. E. (2005). Land cover classification and change analysis of the Twin Cities (Minnesota) Metropolitan Area by multitemporal Landsat remote sensing. Remote Sensing of Environment, 98, 317-328.

[6] Lunetta, R. S. (1998). Applications, project formulation, and analytical approach. In R. S. Lunetta, \& C. D. Elvidge (Eds.), Remote sensing change detection: Environmental monitoring methods and applications. Michigan: Ann Arbor Press.

Dr. V. E. Nethaji Mariappan is

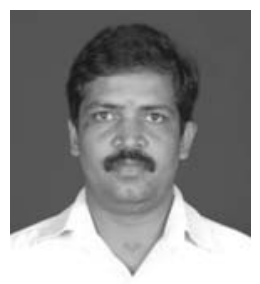
a Scientist-D at the Centre for Remote Sensing and Geoinformatics, Sathyabama University, Chennai. He has done his Doctoral programme at Space Application Centre (ISRO), Ahmedabad. He has over 10 years of research experience in Institutes like Institute of Remote Sensing (IRS) Anna University, Chennai, IARI, New Delhi and SAC (ISRO). His areas of interest include "Natural Resource Management" using Remote Sensing, GIS, Crop Modelling extended to Soil and Agriculture. 